\title{
Effect of Spraying Potassium Silicate at Different Crop Growth Stages on Brown Spot Incidence and Grain Yield of Rice
}

\author{
Jaiganesh, V., Kannan, C., Thamarai Selvi, M. And Sutha Raja Kumar, R. \\ Department of Plant Pathology, Faculty of Agriculture, \\ Annamalai University, Annamalai nagar - 608 002, \\ Cuddalore DT, Tamil Nadu \\ E-mail:potatojaiganesh@gmail.com
}

\begin{abstract}
A field experiment was conducted during Navarai season at Annamalai University Agricultural Experimental Farm using ADT 36 as test cultivar. The efficacy of potassium silicate (3\%) was assessed by spraying it once, twice and thrice at different crop growth stages (15, 30 and 45 DAT- Days After Transplanting). The results indicated that the disease incidence was minimum in plots sprayed thrice with potassium silicate at 15, 30 and 45 DAT, followed by plots received two sprays at 15 DAT and 30 DAT which were statistically at par. The grain yield and straw yield were higher in plots sprayed thrice (15, 30 \& 45 DAT) followed by plots receiving two sprays.
\end{abstract}

Keywords-Rice brown spot, Potassium silicate, crop growth stages, disease incidence

\section{INTRODUCTION}

Rice is a monocotyledonous annual grass belong to family Gramineae and genus Oryza. Currently China and India are ranked 1st and 2nd in rice production according to Foreign Service Association of United States of Department of Agriculture Statistics. Over $90 \%$ of the world's rice is produced and consumed in the Asian region with 6 countries (China, India, Indonesia, Bangladesh, Vietnam and Japan) accounting for about $80 \%$ of the world's production and consumption (Abdullah et al., 2015). Rice crop is widely affected by a number of diseases caused by fungi, bacteria, viruses and mycoplasma which results in considerable yield losse 8 . (Ou, 1985). Among the various fungal diseases of rice, brown spot or sesame leaf spot incited by Helminthosporium oryzae (Breda de Haan) Subram. and Jain (Syn: Bipolaris oryzae (Breda de Haan) Shoemaker) is found to occur in most rice growing areas.

Normally fungicides are primary means of controlling plant diseases. But the use of chemical fungicides is under special scrutiny for posing potential environmental threat as the indiscriminate use of chemical fungicides resulted in environmental pollution and ill-health to biotic community as a whole. Besides, a promising alternative for the control for many rice diseases, including brown spot, is the application of silicon (Si) to soils deficient in this element (Datnoff et al., 2007). In recent years, silicon (Si) is being used for the control of fungal diseases with promising results (Yanar et al., 2011) and silicon accumulation has been reported to be one of the main factors responsible for enhanced resistance against various pathogens of rice (Junior et al., 2009). In this context balanced nutrition seems to be a promising alternative for the control of brown spot (Carvalho et al., 2010). The present paper investigates the Effect of spraying Potassium silicate $(3 \%)$ at different crop growth stages on brown spot incidence and grain yield of rice.

\section{MATERIALS AND METHODS}

Field study was conducted to test the efficacy of potassium silicate $(3 \%)$ for assessing their influence on the incidence of brown spot of rice. The brown spot susceptible variety ADT 36 was used for the study. The experiments were conducted in a randomized block design with thee replications for each treatment and a suitable control. Also, the fertilizer application was done following the blanket schedule of 120:38:38 of N: P: K recommended by the State Agricultural department. A plot size of $5 \mathrm{X} 4 \mathrm{~m}$ was maintained for each treatment and the crop was raised with the spacing of $12.5 \times 10 \mathrm{~cm}$ and all the standard agronomic practices as recommended by the State Agricultural Department were followed. The fungicide carbendazim 50 WP @ 0.1 per cent was used for comparison. The rice crop was harvested at maturity, thrashed, winnowed and cleaned plot wise, dried and the yields of grain and straw were recorded. In all the screening field trials the observations on disease incidence was assessed on a randomly selected set of 


\section{E-ISSN: 2321-9637 \\ Available online at www.ijrat.org}

25 hills per plot at the time of maturity. Also the grain and straw yield of rice was recorded and expressed as t/ha.

A field experiment was conducted during Navarai season at Annamalai University Agricultural Experimental Farm using ADT 36 as test cultivar. The efficacy of potassium silicate (3\%) (Containing $26 \%$ $\mathrm{SiO}_{2}, \mathrm{pH}-5.6$ ) was assessed by spraying it once, twice and thrice at different crop growth stages (15, 30 and 45 DAT). The disease incidence was assessed by adopting 0-9 scale according to "Phytopathometry" by Mayee and Datar (1986) and the per cent disease incidence /index was calculated based on the formula suggested by Vidhyasekaran et al. (1989).

\begin{tabular}{|c|c|}
$\begin{array}{c}\text { DISE } \\
\text { ASE } \\
\text { SEVE } \\
\text { RITY }\end{array}$ & DESCRIPTION OF \\
DISEASE INDEX \\
\hline 0 & No lesions \\
\hline 1 & $\begin{array}{l}\text { Affected leaf area less than } \\
1 \%\end{array}$ \\
\hline 3 & $1-10 \%$ affected leaf area \\
\hline 5 & $11-25 \%$ affected leaf area \\
\hline 7 & $26-50 \%$ affected leaf area \\
\hline 9 & $>50 \%$ leaf area affected \\
\hline \multicolumn{2}{|c|}{ Ter cent Disease Index = ratings } \\
x $100 \quad$ notal \\
\hline
\end{tabular}

Maximum grade

\section{Straw yield}

After thrashing and separation of grains, the straw was dried pot wise / plot wise in sun for two days. Later, the straw weight was weighed and computed to tha-1.

\section{Grain yield}

The matured crop was harvested and the grains were hand threshed, winnowed and sun dried sufficiently. The dried grains were weighed plot wise and then converted into per hectare basis and expressed as tha-1.

\section{Biological yield}

The biological yield was calculated by the summation of grain and straw yield and recorded as $t$ ha-1.

\section{RESULTS AND DISCUSSION}

The data indicated that the disease incidence was minimum $(17.30 \%)$ in plots sprayed thrice with potassium silicate $(3 \%)$ at 15,30 and 45 DAT, followed by plots received two sprays at 15 DAT and 30 DAT $(17.42 \%)$ which were statistically at par (Table 11). The grain yield and straw yield were higher in plots sprayed thrice $(15,30$ \& 45 DAT) followed by plots receiving two sprays. The control plot recorded 37.06 per cent of disease incidence, 4.05 $\mathrm{t} / \mathrm{ha}$ of grain yield is and $5.98 \mathrm{t} / \mathrm{ha}$ of straw yield.

Several studies have demonstrated that the severity of foliar diseases of various crops including rice can be reduced through foliar or soil applications of potassium silicate (Guevel et al., 2007; Buck et al., 2008; Dallagnol et al., 2009).

Rodrigues et al. (2003) stated that silicon fertilization to rice crop reduced the incidence of sheath blight. Martinati et al. (2008) proved that potassium silicate treated coffee plants improved the production, productivity and increased the resistance against coffee rust caused by Hemileia vastatrix.

Rezende et al. (2009) proved that root and foliar application of potassium silicate can decrease the intensity of brown spot of rice. The ability of soluble silicon $(\mathrm{Si})$ to reduce the impact of plant diseases has been sufficiently described in the rice and various crops (Rodrigues et al., 2003; Kim et al., 2002). Liang et al., (2005) suggested that disease reduction caused by foliar sprays of potassium silicate was the result of an osmotic effect on spores germinating at the leaf surface.

It has been reported that potassium fertilizer application can decrease brown spot severity on rice (Carvalho et al., 2010). The brown spot disease of rice is usually associated with an imbalance of $\mathrm{K}$ (potassium) and $\mathrm{N}$ (nitrogen) in rice leaf tissue and $\mathrm{K}$ is able to reduce disease intensity (Baba et al., 1958). The potassium content in potassium silicate could have also contributed to the enhanced disease suppression. Further, silicon, in the form of silicic acid, would act locally by inducing defense reactions in elicited cells and would also contribute to systemic resistance by enhancing the production of stress hormones (Fauteux et al., 2005). Thus, the above reasons could be attributed for the efficacy of foliar sprays of potassium silicate, in reducing the brown spot incidence of rice. 


\section{Available online at www.ijrat.org}

Table 1. Effect of spraying Potassium silicate (3\%) at different crop growth stages on brown spot incidence and grain yield of rice var. ADT 36 (Field experiment)

\begin{tabular}{|c|c|c|c|c|c|}
\hline $\begin{array}{c}\text { Treatm } \\
\text { ents }\end{array}$ & $\begin{array}{c}\text { Stages of } \\
\text { spraying }\end{array}$ & $\begin{array}{c}\text { Disease } \\
\text { incidence } \\
(\boldsymbol{\%})\end{array}$ & $\begin{array}{c}\text { Grain } \\
\text { yield } \\
\mathbf{( t / h a )}\end{array}$ & $\begin{array}{c}\text { Straw } \\
\text { yield } \\
(\mathbf{t} / \mathbf{h a})\end{array}$ & $\begin{array}{c}\text { Biological } \\
\text { Yield }\end{array}$ \\
\hline $\mathrm{T}_{1}$ & $15 \mathrm{DAT}$ & 22.89 & 4.63 & 6.80 & 11.43 \\
\hline $\mathrm{T}_{2}$ & $30 \mathrm{DAT}$ & 20.48 & 4.84 & 7.05 & 11.89 \\
\hline $\mathrm{T}_{3}$ & $45 \mathrm{DAT}$ & 23.42 & 4.50 & 6.67 & 11.17 \\
\hline $\mathrm{T}_{4}$ & $\mathrm{~T}_{1}+\mathrm{T}_{2}$ & 17.42 & 5.07 & 7.15 & 12.22 \\
\hline $\mathrm{T}_{5}$ & $\mathrm{~T}_{1}+\mathrm{T}_{3}$ & 20.00 & 4.93 & 7.12 & 12.05 \\
\hline $\mathrm{T}_{6}$ & $\mathrm{~T}_{2}+\mathrm{T}_{3}$ & 19.55 & 4.99 & 7.12 & 12.11 \\
\hline $\mathrm{T}_{7}$ & $\begin{array}{c}\mathrm{T}_{1}+\mathrm{T}_{2}+ \\
\mathrm{T}_{3}\end{array}$ & 17.30 & 5.10 & 7.22 & 12.32 \\
\hline $\mathrm{T}_{8}$ & $\begin{array}{c}\text { Carbendazi } \\
\mathrm{m} 0.1 \%\end{array}$ & 13.38 & 4.55 & 6.50 & 11.05 \\
\hline $\mathrm{T}_{9}$ & Control & 37.06 & 4.05 & 5.98 & 10.03 \\
\hline \multicolumn{2}{|c}{ C.D. (p=0.05) } & 5.32 & 0.18 & 0.14 & 0.09 \\
\hline
\end{tabular}

\section{REFERENCES}

[1] Abdullah, M., Li, J., Ghazanfar, S., Khan, I. Ishaq, M.N. and Ahmed, J. (2015). Domestic Rice Marketing Structure and Marketing Margins in Pakistan. Journal of Economics and Sustainable Development. 6:12, 226-238.

[2] Baba, I., Takahashi, Y. and Swata, I. (1958).Nutritional studies on the occurrence of Helminthosporium leaf spot and akiochi of the rice plant. Bull. Nat. Inst.Agri.Sci., Tokyo, 17: 1157.

[3] Buck, G. B., Korndörfer, G. H., Nolla, A. and Coelho, L. (2008). Potassium Silicate as Foliar Spray and Rice Blast Control. J. of Pl. Nutri., 31: 231-237.

[4] Carvalho, M.P., Rodrigues, F.A., Silveria, P.R., Andrade, C.C.L., Baroni, J.C.P., Paye, H.S. and Junior, J.E.L. (2010). Rice resistance to brown spot mediated by Nitrogen and Potassium. J. Phytopathol., 158: 160-166.

[5] Dallagnol, L.J., Rodrigues, F.A., Mielli, M.V.B., Ma, J.F. and Datnoff, L.E. (2009). Defective active silicon uptake affects some components of rice resistance to brown spot. Phytopathology, 99: $116-121$.

[6] Datnoff, L.E., Rodrigues, F.A. and Seebold, K.W. (2007). Silicon and plant disease. In: Datnoff,

[7] L.E., Elmer, W.H., Huber, D.M. (Eds.). Mineral nutrition and plant disease. Saint Paul MN. APS Press, pp. 233-246.

[8] Fauteux, F., Remus-Borel, W., Menzies, J. G. and Belanger, R. R. (2005). Silicon and plant disease
(A.1)

resistance against pathogenic fungi. FEMS Microbiology Letters 249: 1-6.

[9] Guevel, M.H., Menzies, J.G. and Belanger, R.R. (2007). Effect of root and foliar applications of soluble silicon on powdery mildew control and growth of wheat plants. European Journal of Plant Pathology, 119: 429-436.

[10] Junior, L.A.Z., Rodrigues, F.A., Fontes, R.L.F., Korndorfer, G.H. and Neves, J.C.L. (2009). Rice resistance to Brown spot mediated by Silicon and its interaction with Manganese. J. Phytopathology, 157:73 - 78 .

[11] Kim, S.G., Kim, K.W., Park, E.W. and Choi, D. (2002). Silicon-induced cell wall fortification of rice leaves: A possible cellular mechanism of enhanced host resistance to blast. Phytopathol., 92: 1095-1103.

[12]Liang, Y.C., Sun, W.C., Si, J. and Romheld, V. (2005). Effects of foliar and root-applied silicon on the enhancement of induced resistance to powdery mildew in Cucumis sativus. Plant Pathol., 54: 678-685.

[13] Martinati, J.C., Harakava, R., Guzzo, S.D. and Tsai, S.M. (2008). The potential use of a silicon source as a component of an ecological management of coffee plants. J. Phytopathology, $156: 458-463$.

[14] Mayee, C.D. and Datar, V.V. (1986). "Phytopathometry" - Technical bulletin-I (Special Bulletin 3). Marathwada Agricultural University, Parbhani, 218p.

[15] Ou,S.H. 1985, Rice Diseases, 2nd Edition, Common Wealth Mycological Institute, U.K. $380 \mathrm{p}$. 
International Journal of Research in Advent Technology, Vol.7, No.1, January 2019 E-ISSN: 2321-9637

\section{Available online at www.ijrat.org}

[16] Rezende, D.C., Rodrigues, F.A., Carre -Missio, V., Schurt, D.A., Kawamura, I.K. and Korndorfer, G.H. (2009). Effect of root and foliar application of silicon on brown spot development in rice. Aus. Plant Pathol., 38: 67-73.

[17] Rodrigues, F. A., Benhamou, N., Datnoff, J. B., Jones, B. and Bélanger, R. R. (2003). Ultrastructural and cytochemical aspects of silicon-mediated rice blast resistance. Phytopathol., 93: 535-546.

[18] Vidhyasekaran, P., Umapathy,G., Gopalan,M., Ramakrishnan,G. and Sivaprakasam,K. (1989). Pest and Disease Surveillance, Centre for Plant Protection Studies, Tamil Nadu Agricultural University, Coimbatore-3. 237 p.

[19] Yanar, Y., Yanar, D. and Gebologlu, N. (2011). Control of powdery mildew (Leveillula taurica) on tomato by foliar sprays of liquid potassium silicate $\left(\mathrm{K}_{2} \mathrm{SiO}_{3}\right)$. African J. of Biotechnology., 10(16): 3121-3123. 